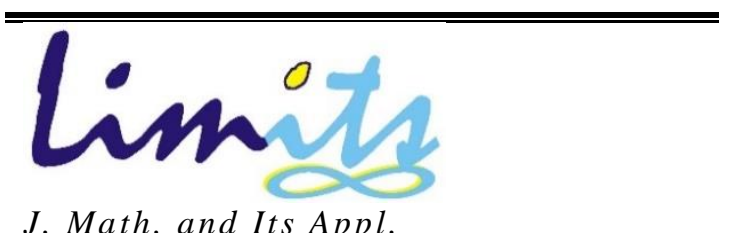

J. Math. and Its Appl.

ISSN: $1829-605 \mathrm{X}$

Vol. 13, No. 2, Nopember 2016, 45-52

\title{
ANALISIS EKSISTENSI TRAVELING WAVE FRONT PADA MODEL MATEMATIKA REASSORTMENT VIRUS INFLUENSA H5N1 DAN H1N1-p
}

\author{
Hariyanto $^{1}$, Suharmadi Sanjaya ${ }^{2}$, Sri Suprapti ${ }^{3}$ \\ ${ }_{1,2,3}$ Laboratorium Pemodelan dan Simulasi Sistem \\ Jurusan Matematika FMIPA-ITS \\ hariyanto@matematika.its.ac.id
}

\begin{abstract}
Abstrak
Reassortment dari virus influensa adalah transmisi dari lebih dari satu virus pada satu species yang dapat terjadi pada satu maupun beberapa lokasi, transmisi virus dapat terjadi karena kontak individual pada masing-masing lokasi atau pada lokasi silang. Jika penyebaran virus pada multilokasi terjadi pada multi species dan multi strain maka analisa traveling wave front dapat dilakukan berdasarkan pada model sistem persamaan differensial parsialintegral. Pada makalah ini merupakan hasil penelitian dengan mengembangkan model penyebaran virus pada 2 lokasi dengan setiap lokasi mempunyai potensi untuk terjadinya reassortment virus influensa H5N1 dengan H1N1-p, pergerakan individual secara lokal maupun global sangat mempengaruhi konstruksi model penyebaran virus yang dibangun, oleh karena itu analisa terhadap eksistensi traveling wave front dalam rangka untuk mengetahui potensi terjadinya penyebaran secara luas.

Kata Kunci: Pemodelan Epidemik, Model Spasial, Traveling wave front
\end{abstract}

\section{Pendahuluan}

Reassortment virus terjadi jika material genetika dari beberapa species bergabung dan akan menghasilkan species baru yang mempunyai karakteristik berbeda tetapi masih mempunyai garis keturunan dari species sebelumnya, koalisi dari virus influensa terjadi berasal dari genome yang terdiri dari 8 segmen berbeda pada RNA dan segmen-segmen tersebut mirip dengan minikromosom yang setiap saat akan menyatu. Jika host yang berperan sebagai mixing vessel terinfeksi oleh 2 virus dengan strain yang berbeda maka kemungkinan yang terjadi adalah terbentuk pasangan viral partikel baru oleh segmen-segmen asli yang dapat berasal dari salah satu 
strain, Pasangan viral partikel tersebut disebut sebagai strain baru yang akan menjadi bagian dari kedua virus tersebut atau garis keturunannya.

Berdasarkan pada kasus yang telah terjadi pada virus influensa sebelumnya reassortment mayoritas berbentuk genetik shift, Hal ini misalnya pandemik dari strain flu pada tahun 1957 virus influensa Asian H2N2, dan suspect pada reassortment dari avian H5N1, dan pada tahun 1918 dengan virus H1N1. Ditemukan sirkulasi semua virus H5N1 mempunyai gen HA dan Na yang terjadi di A/Goose/Guangdong/I/1996, Dan pada tahun 1968 terjadi reassortment antara virus avian dan virus manusia, Pada tahun 2009 terjadi mixing outbreak flu swine yang merupakan gabungan dari rangkaian genetik influensa swine, avian dan manusia, Antigenik shift merupakan kasus khusus dari reassortment atau viral shift yang mempunyai perubahan phenotype, Hal ini dapat didefinisikan sebagai proses oleh paling sedikit 2 strain dari virus, Khususnya influensa, yang mengkombinasikan strain tersebut untuk membentuk subtipe baru yang terjadi dari campuran permukaan antigen dari 2 strain asli.

Virus influensa yang beredar di Indonesia terdiri dari virus-virus H1N1,H3N2,H1N1-p,dan H5N1 yang terdiri dari 170 varian dengan 3 jenis penyerangan yang berbeda-beda,berdasarkan pada kenyataan bahwa penyebaran virus influensa dapat terjadi pada lokasi yang berbeda dengan strain yang berbeda, misalnya penyebaran virus influenza avian H5N1 secara global yang terjadi di Indonesia berpotensi terjadinya koalisi dengan virus manusia, beberapa penelitian di laboratorium telah dilakukan antara lain koalisi antara H5N1 unggas A/Chicken/South Kalimantan/UT6028/06(SK06 H5N1) dan H3N2 A/Tokyo/UT-SK-1/Tok07.H3N2 menghasilkan virus dengan patogen tinggi $[7,10]$.

Model matematika yang dibangun berdasarkan pada penyebaran virus baik lokal maupun global telah dilakukan antara lain: kontruksi model berdasarkan penyebaran virus satu strain satu species pada multi lokasi menghasilkan sistem persamaan differensial biasa yang dapat menganalisa korelasi penyebaran lokasi lain dengan lokasi pusat penyebaran [1,5]. Konstruksi model juga dibuat berdasarkan pada lokasi spasial dengan anggapan bahwa populasi sebagai partikel yang bergerak bebas, model ini mencerminkan penyebaran global pada 2 lokasi dengan strain yang sama maupun species yang sama [3,411], berikutnya model yang dikonstruksi dengan mengembangkan model [11] akan tetapi dibedakan berdasarkan individual yang terinfeksi dan pergerakan individual pada masing-masing lokasi dan hasil yang diperoleh berbentuk sistem persamaan differensial parsial integral $[8,11,13]$. Model yang telah dibuat sangat relevan dengan makalah yang dibahas yaitu lokasi spasial dengan multispecies multistrain pada masing-masing lokasi, konstruksi model untuk penyebaran multi strain multi species pada satu lokasi telah dibuat dan analisa terhadap model traveling wave dapat mengetahui penyebaran virus super strain.

Pada makalah ini model dikontruksi berdasarkan pada individual sebagai partikel bebas yang bergerak pada 2 lokasi dengan masing-masing lokasi terdapat penyebaran virus dengan strain yang berbeda, analisa terhadap 
eksistensi traveling wave front dilakukan pada model traveling wave yang dibangun dari model penyebaran global berbentuk sistem persamaan differensial parsial integral dan hasil dari analisa dapat mengetahui tentang potensi terjadinya penyebaran virus yang lebih luas, struktur pembahasan pada makalah ini antara lain landasan teori yang digunakan untuk melakukan kajian dibahas pada §II, metode yang dilakukan pada §III, hasil yang diperoleh pada §IV dan kesimpulan dari analisa yang dilakukan akan dibahas pada $\S \mathrm{V}$.

\section{Teori Penunjang}

Pada bab ini akan menjelaskan tentang teori dasar yang menunjang dalam melakukan kajian antara lain teori pemodelan matematika, oleh karena model dikonstruksi dalam sistem maka masing masing lokasi dinyatakan sebagai subsistem dan masing-masing subsistem dihubungkan oleh interface agar supaya model matematika yang terbentuk menjadi model yang saling terkait. Diantara persamaan-persamaan, interface individual diantara lokasi dan transmisi silang diantara lokasi [4].

Hukum-hukum dasar yang digunakan dalam melakukan kajian pada makalah ini adalah:

1. Model sistem kompartemen, sistem dianggap sebagai perubahan populasi yang terbagi menjadi beberapa subpopulasi sehingga perubahan setiap subpopulasi adalah

2. $\sum$ (perubahan individual karena sifat epidemiologi + gerakan individual yang masuk) ${ }^{\text {masuk }}$ - (perubahan individual karena sifat epidemiologi + gerakan individual yang keluar) ${ }^{\text {keluar }}$, oleh karena individual dianggap sebagai partikel bebas maka digunakan persamaan reaksi diffusi berbentuk

$\frac{\partial P(x, t)}{\partial t}=d(x) \nabla P(x, t)+f(x, t, P(x, t))$

dengan $P(x, t)$ fungsi densitas populasi, $d(x) \nabla P(x, t)$ bagian dari diffusi dan $f(x, t, P(x, t))$ bagian dari reaksi [3,13].

3. Misalkan populasi dibagi dalam 2 bagian yaitu $S(x, t)$ dan $I(x, t)$ maka persamaan reaksi diffusi dapat dinyatakan dalam bentuk:

$$
\begin{aligned}
& \frac{\partial S(x, t)}{\partial t}=d(x) \nabla S(x, t)+f(x, t, S(x, t)) \\
& \frac{\partial I(x, t)}{\partial t}=d(x) \nabla I(x, t)+f(x, t, I(x, t))
\end{aligned}
$$

Penyelesaian dari traveling wavefront dari persamaan (2) adalah penyelesaian berbentuk $S(x, t)=S(u), I(x, t)=I(u)$ dengan $u=x+$ $c t$ dan $c$ sebagai kecepatan gelombang. Untuk melakukan analisa terhadap eksistensi traveling wave front digunakan definisi dan theorema sebagai berikut:

\section{Definisi 1.}

Penyelesian traveling wavefront dengan kecepatan $c$ untuk model sistem (2) adalah penyelesaian yang mempunyai bentuk $(S(x+c t), I(x+c t))$ dan berhubungan dengan titik kesetimbangan penyakit endemik dan bebas penyakit dari sistem sehingga 


\section{Teorema 1}

$$
\begin{aligned}
& \lim _{u \rightarrow+\infty}(S, I)=\left(S^{*}, I^{*}\right) \\
& \text { dan } \\
& \lim _{u \rightarrow-\infty}(S, I)=\left(S_{\infty}, 0\right)
\end{aligned}
$$

Jika kecepatan minimal dari traveling wave adalah $c^{*}$ sedemikian hingga untuk setiap $c \geq c^{*}$ maka pada model sistem tak linear akan mempunyai penyelesaian traveling wavefront non increasing $(S(x+c t), I(x+c t))$ dengan kecepatan $c$ yang memenuhi $\lim _{u \rightarrow+\infty}(S, I)=\left(S^{*}, I^{*}\right)$ dan $\lim _{u \rightarrow-\infty}(S, I)=\left(S_{\infty}, 0\right)[2,8,12]$.

\section{Konstruksi Model Penyebaran Virus}

Populasi berada dalam 2 lokasi yaitu lokasi $\Omega_{1}$ dengan ukuran $L_{1}$ dan lokasi $\Omega_{2}$ dengan ukuran $L_{2}$ dan pada masing-masing lokasi populasi dibagi dalam subpopulasi-subpopulasi pada lokasi 1 dan lokasi 2 yang terdiri dari Susceptible, Ekspose, Terinfeksi dengan densitas spasial $S_{11}(x, t), E_{11}(x, t), I_{11}(x, t)$ untuk virus H1N1-p dan Susceptible, Terinfeksi dengan densitas spasial $S_{21}(x, t), I_{21}(x, t)$ untuk virus H5N1.

Konstruksi model reassortment kedua virus dinyatakan dalam bentuk

$$
\begin{aligned}
& \frac{\partial S_{11}}{\partial t}=D_{1}^{I_{11}} \frac{\partial^{2} S_{11}}{\partial x^{2}}-\alpha S_{11} I_{11}-\beta^{*} S_{11} I_{21}-\beta^{*} S_{11} I_{22}+b_{1} S_{11}-d_{1} S_{11}+\gamma E_{11} \\
& \quad-\int_{\Omega} K(y-x) S_{11} d x+\int_{\Omega} K(y-x) S_{12} d x+\delta I_{11} \\
& \begin{aligned}
\frac{\partial I_{11}}{\partial t}=D_{1}^{I_{11}} \frac{\partial^{2} I_{11}}{\partial x^{2}}+\gamma E_{11}-\delta I_{11}-b_{1} I_{11}-d_{1} I_{11}+\beta^{*} S_{11} I_{21}+\beta^{*} S_{11} I_{22}-\int_{\Omega} K(y- \\
x) I_{11} d x+\int_{\Omega} K(y-x) S_{12} d x \\
\frac{\partial S_{21}}{\partial t}=D_{1}^{S_{21}} \frac{\partial^{2} S_{21}}{\partial x^{2}}-\alpha S_{11} I_{11}-\beta S_{21} I_{21}-\beta S_{21} I_{22}+b_{2} S_{21}-d_{2} S_{21} \\
\quad-\int_{\Omega} K(y-x) S_{21} d x+\int_{\Omega} K(y-x) S_{22} d x \\
\frac{\partial I_{21}}{\partial t}=D_{1}^{I_{21}} \frac{\partial^{2} I_{21}}{\partial x^{2}}+b_{2} I_{21}-d_{2} I_{21}+\beta S_{21} I_{21}+\beta S_{21} I_{22}-\int_{\Omega} K(y-x) I_{21} d x+\int_{\Omega} K(y-x) I_{22} d x
\end{aligned}
\end{aligned}
$$

Dengan syarat awal

$$
S_{11}(x, 0)=S_{10}=\sigma, I_{11}(x, 0)=I_{10}, S_{21}(x, 0)=S_{210}, I_{21}(x, 0)=I_{210}
$$

Syarat batas

$$
\begin{aligned}
& \frac{\partial S_{11}}{\partial t}(0)=\frac{\partial S_{11}}{\partial t}(L)=0, \frac{\partial I_{11}}{\partial t}(0)=\frac{\partial I_{11}}{\partial t}(L)=0 \\
& \frac{\partial S_{21}}{\partial t}(0)=\frac{\partial S_{21}}{\partial t}(L)=0, \frac{\partial I_{21}}{\partial t}(0)=\frac{\partial I_{21}}{\partial t}(L)=0
\end{aligned}
$$

Parameter yang digunakan dalam bentuk konstan antara lain :

- $\alpha$ rate transmisi H1N1-p, $\beta^{*}$ rate transmisi H5N1 dari unggas ke manusia,

- $\beta$ rate transmisi $\mathrm{H} 5 \mathrm{~N} 1$ dari unggas ke unggas, $\mathrm{b}_{1}$ rate mortalitas manusia,

- $d_{1}$ rate kematian pada manusia, $\delta$ rate recovery pada manusia,

- $\gamma$ periode ekspose pada manusia, $b_{2}$ rate mortalitas pada unggas,

- $d_{2}$ rate kematian pada unggas, 
- $\varepsilon_{1} \varepsilon_{2}$ besaran yang menyatakan bobot dari gerakan individual bergerak pada lokasi yang sama atau pada lokasi lain $0<\varepsilon_{1}, \varepsilon_{2}<1$.

\section{Analisa Eksistensi Traveling Wavefront}

Model traveling wave dikonstruksi dari model penyebaran virus dengan melakukan trasnformasi $u=x+c t, c$ sebagai kecepatan penyebaran sehingga diperoleh model traveling wave berbentuk $I_{11}(x, t)=I_{11}(u), I_{21}(x, t)=I_{21}$ untuk lokasi 1 dan untuk lokasi 2 diperoleh $I_{12}(x, t)=I_{12}(u), I_{22}(x, t)=I_{22}(u)$.

Model traveling wave pada lokasi 1 adalah model dari penyebaran $\mathrm{H} 1 \mathrm{~N} 1-$ p dan $\mathrm{H} 5 \mathrm{~N} 1$ pada manusia.dan penyebaran $\mathrm{H} 5 \mathrm{~N} 1$ pada unggas adalah:

$\frac{\partial I_{11}}{\partial t}=D_{1}^{I_{11}} \frac{\partial^{2} I_{11}}{\partial x^{2}}+\gamma E_{11}-\delta I_{11}-b_{1} I_{11}-d_{1} I_{11}+\beta^{*} S_{11} I_{21}+\beta^{*} S_{11} I_{22}+\varepsilon_{2} I_{11}-\varepsilon_{1} I_{11}$

$\frac{\partial I_{21}}{\partial t}=D_{1}^{I_{21}} \frac{\partial^{2} I_{21}}{\partial x^{2}}-b_{2} I_{21}-d_{2} I_{21}+\beta S_{21} I_{21}+\beta S_{21} I_{22}+\varepsilon_{2} I_{21}-\varepsilon_{1} I_{21}$

bagian persamaan berbentuk $\gamma E_{11}$ yaitu individual pada subpopulasi ekspose yang berubah menjadi individual terinfeksi yang dapat dinyatakan dalam bentuk model travelling wavefront menjadi dengan $f_{\kappa}$ adalah transformasi Fourier dari individual terinfeksi pada kondisi latent

$$
\kappa \int_{-\infty}^{\infty} \alpha S_{11}(u-y-c \tau) I_{11}(u-y-c \tau) f_{\kappa} d y
$$

Dengan demikian model traveling wavefront adalah

$$
\begin{aligned}
& D_{1}^{I_{11}} \frac{d^{2} I_{11}}{d x^{2}}-c \frac{d I_{11}}{d t}+\kappa \int_{-\infty}^{\infty} \alpha S_{11}(u-y-c \tau) I_{11}(u-y-c \tau) f_{\kappa} d y-\delta I_{11}-b_{1} I_{11}-d_{1} I_{11} \\
& \quad+\beta^{*} S_{11} I_{21}+\beta^{*} \varepsilon_{2} S_{11} I_{21}+\varepsilon_{2} I_{11}-\varepsilon_{1} I_{11}=0 \\
& D_{1}^{I_{21}} \frac{d^{2} I_{21}}{d x^{2}}-c \frac{d I_{21}}{d t}-b_{2} I_{21}-d_{2} I_{21}+\beta S_{21} I_{21}+\beta S_{21} I_{22}+\varepsilon_{2} I_{21}-\varepsilon_{1} I_{21}=0
\end{aligned}
$$

Titik kesetimbangan bebas penyakit pada penyebaran virus H1N1-p dan virus H5N1 adalah $\left(S_{11}^{o}(x, t), I_{11}^{o}(x, t)\right)=\left(S_{21}^{o}(x, t), I_{21}^{o}(x, t)\right)=\frac{\sigma}{d_{1}-b_{1}+\varepsilon_{1}-\varepsilon_{2}}$ atau $\left(\frac{\sigma}{\vartheta_{1}}, 0\right)$, dengan syarat batas sebagai berikut:

$$
\begin{gathered}
\lim _{u \rightarrow-\infty}\left(I_{11}(u), I_{21}(u)\right)=\left(I_{11}^{o}(x, t), I_{21}^{o}(x, t)\right) \\
\text { dan } \\
\lim _{u \rightarrow+\infty}\left(I_{11}(u), I_{21}(u)\right)=\left(I_{11}^{*}(x, t), I_{21}^{*}(x, t)\right.
\end{gathered}
$$

Linearisasi terhadap model traveling wavefront penyebaran H1N1-p dan H5N1 pada lokasi 1 di sekitar titik kesetimbangan bebas virus. adalah

$$
\begin{gathered}
D_{1}^{I_{11}} \frac{d^{2} I_{11}}{d x^{2}}-c \frac{d I_{11}}{d t}+\kappa \int_{-\infty}^{\infty} \frac{\sigma \alpha}{\vartheta_{1}} I_{11}(u-y-c \tau) f_{\kappa} d y-\delta I_{11}-b_{1} I_{11}-d_{1} I_{11}+\frac{\sigma \beta^{*}}{\vartheta_{1}} I_{21}+\frac{\sigma \beta^{*} \varepsilon_{2}}{\vartheta_{1}} I_{21} \\
\quad+\varepsilon_{2} I_{11}-\varepsilon_{1} I_{11}=0 \\
D_{1}^{I_{21}} \frac{d^{2} I_{21}}{d x^{2}}-c \frac{d I_{21}}{d t}-b_{2} I_{21}-d_{2} I_{21}+\frac{\sigma \beta}{\vartheta_{1}} I_{21}+\frac{\sigma \beta \varepsilon_{2}}{\vartheta_{1}} I_{22}+\varepsilon_{2} I_{21}-\varepsilon_{1} I_{21}=0
\end{gathered}
$$

jika penyelesaian dari model tersebut adalah $\left(k_{1} e^{\lambda u}, k_{2} e^{\lambda u}\right)$ maka akan diperoleh

$g(\lambda, c) h(\lambda, c)=\left(D_{1}^{I_{11}} \lambda^{2}-c \lambda-\xi+\frac{\sigma \alpha \kappa}{\vartheta_{1}} e^{\tau D_{1}^{I_{11}} \lambda^{2}-\lambda c \tau}\right)\left(D_{1}^{I_{21}} \lambda^{2}-c \lambda-\theta\right)=0$ 
Jika $\frac{\partial g}{\partial \lambda}=\frac{\partial h}{\partial \lambda}=0$ maka diperoleh $\lambda_{1}=\frac{c}{2 D_{1}^{I_{11}}}>0$ dan $\lambda_{2}=\frac{c}{2 D_{1}^{I_{11}}}>0$, dari nilai $\lambda$ tersebut dapat diperoleh persamaan $\left(\frac{c^{2}}{4 D_{1}^{I_{21}}}-\theta\right)\left(\frac{c^{2}}{2 D_{1}^{I_{11}}}-\xi+\frac{\kappa \sigma \alpha}{\vartheta_{1}} e^{\frac{c^{2} \tau}{4 D_{1}^{11}}}\right)=0$ dan memberikan jawaban tentang kecepatan minimal $c^{*}$.

Jika $D_{1}^{I_{11}}=D_{1}^{I_{21}}=D_{1}, z^{*}=\frac{c^{2}}{2 D_{1}} \Rightarrow c^{*}=\sqrt{2 D_{1} Z^{*}}$ diperoleh $\left(\frac{z^{*}}{2}-\theta\right)\left(z^{*}-\xi\right)=0$ untuk $\tau=$ 0 yang akan memberikan 2 kecepatan minimal yaitu $c^{*}=\sqrt{4 D_{1} \theta}$ untuk $z^{*}=2 \theta$ dan $c^{*}=\sqrt{2 D_{1} \xi}$ untuk $z^{*}=\xi$ dengan $b_{1}+d_{1}-\varepsilon_{2}+\varepsilon_{1}+\delta=\xi$ dan $\varepsilon_{1}-b_{2}+d_{2}+$ $\frac{\sigma \beta\left(1+\varepsilon_{2}\right)}{\vartheta_{2}}-\varepsilon_{2}=\theta$

Model traveling wave pada Lokasi 2 merupakan penyebaran H5N1dan H1N1-p pada manusia dan kecepatan minimal $c^{*}$ dapat diperoleh dengan langkah-langkah seperti pada lokasi 1 yang menghasilkan persamaan khusus berbentuk $\left(\frac{c^{2}}{D_{1}^{I_{22}}}-\theta\right)\left(\frac{c^{2}}{2 D_{1}^{I_{12}}}-\xi+\frac{\kappa \sigma \alpha}{\vartheta_{1}} e^{\frac{c^{2} \tau}{\mu^{D_{12}}}}\right)=0$, jika $D_{1}^{I_{12}}=D_{1}^{I_{22}}=D_{1}$ dan $z^{*}=\frac{c^{2}}{2 D_{1}} \Rightarrow$ $c^{*}=\sqrt{2 D_{1} Z^{*}}$ sehingga diperoleh $\left(\frac{z^{*}}{2}-\theta\right)\left(z^{*}-\xi\right)=0$ untuk $\tau=0$ yang akan memberikan 2 kecepatan minimal yaitu $c^{*}=\sqrt{4 D_{1} \theta}$ untuk $z^{*}=2 \theta$ dan $c^{*}=\sqrt{2 D_{1} \xi}$ untuk $z^{*}=\xi$ dengan $b_{1}+d_{1}-\varepsilon_{2}+\varepsilon_{1}+\delta=\xi$ dan $\varepsilon_{1}-\mathrm{b}_{2}+\mathrm{d}_{2}+\frac{\sigma \beta\left(1+\varepsilon_{2}\right)}{\vartheta_{2}}-\varepsilon_{2}=0$

Model traveling wave front global adalah penyebaran virus $\mathrm{H} 5 \mathrm{~N} 1$ pada unggas secara global, analisa traveling wavefront dilakukan terhadap pergerakan indvidual susceptible pada lokasi 1 dan penyebaran pandemik dari virus H5N1 yang terjadi pada unggas pada lokasi 2.

Penyelesaian model traveling wavefront $\left(k_{1} e^{\lambda u}, k_{2} e^{\lambda u}\right)$ dapat menghasilkan parameter $\lambda$ berbentuk $\lambda_{1}=\frac{c}{2 D_{1}^{S_{11}}}, \lambda_{2}=-\frac{c}{2 D_{2}^{S_{22}}}$ dan persamaan $\left(\frac{c^{2}}{4 D_{2}^{I_{22}}}-2 v\right)\left(\frac{\vartheta_{1} c^{2}}{4 S_{1}^{S_{11}}}-\vartheta_{1} \eta\right)=0$, jika $D_{1}^{S_{11}}=D_{2}^{I_{22}}=D, z^{*}=\frac{c^{2}}{4 D} \Rightarrow c^{*}=\sqrt{4 D z^{*}}$ maka $\quad\left(z^{*}-\right.$ $2 v)\left(\vartheta_{1} z^{*}-\vartheta_{1} \eta\right)=0$ menghasilkan kecepatan minimal yaitu $c^{*}=\sqrt{8 D v}$ untuk $z^{*}=$ $2 v$ dan $c^{*}=\sqrt{4 D \eta}$ dengan $v=b_{2}-d_{2}+\frac{\beta \sigma \varepsilon_{2}}{\vartheta_{1}}+\frac{\beta \sigma}{\vartheta_{1}}-\varepsilon_{1}+\varepsilon_{2}, \eta=d_{1}-b_{1}+\varepsilon_{1}-\varepsilon_{2}$.

\section{Analisa Persistensi Traveling Wavefront}

Jika $\left(I_{11}(u), I_{21}(u)\right)=\left(k_{1} e^{\lambda u}, k_{2} e^{\lambda u}\right)$ adalah penyelesaian dari model traveling wavefront berbentuk $\left(D_{1}^{I_{11}} \lambda^{2}+c \lambda-\xi+\frac{\kappa \sigma \alpha}{\vartheta_{1}} e^{\tau D_{1}^{I_{11} \lambda^{2}-\lambda c \tau}}\right)\left(D_{1}^{I_{12}} \lambda^{2}+c \lambda-\theta\right)=0$, untuk $\lambda_{1}=-\frac{c}{2 D_{121}^{I}}<0$ berlaku $g(\lambda, c)=D_{111}^{I} \lambda^{2}+c \lambda-\xi+\frac{\kappa \sigma \alpha}{\vartheta_{1}} e^{\tau D_{1}^{I_{11} \lambda^{2}-\lambda c \tau}}$ dan $\sup (g(\lambda, c))=c \lambda-$ $\xi+\frac{\kappa \sigma \alpha}{\vartheta_{1}} e^{\tau D_{1}^{I_{1}} 1 \lambda^{2}-\lambda c \tau}$ sehingga $\lim _{\lambda \rightarrow \infty} \sup (g(\lambda, c))>\xi$ atau dapat dinyatakan sebagai $\lim _{u \rightarrow \infty} \sup \left(I_{11}(u)\right)>\xi$ untuk $b_{1}+d_{1}-\varepsilon_{2}+\varepsilon_{1}+\delta=\xi$. Jadi terdapat weakly uniformly persistence pada traveling wavefront terhadap kecepatan penyebaran virus H1N1-p pada lokasi 1.

Dengan cara yang sama dapat juga dilakukan analisa terhadap kecepatan penyebaran virus $\mathrm{H} 5 \mathrm{~N} 1$ dan menghasilkan strongly uniformly persistence pada lokasi 2.

Berdasarkan analisa tersebut di atas dapat diperoleh hubungan antara persistensi dengan kecepatan minimal $c^{*}$ pada masing-masing lokasi penyebaran virus yaitu

\section{Lokasi 1}


Virus H1N1-p dengan kecepatan minimal $c^{*}=\sqrt{2 D_{1} \xi}, b_{1}+d_{1}-\varepsilon_{2}+\varepsilon_{1}+\delta=\xi$ dengan persistensi weakly uniformly persistence.

Virus H5N1 dengan kecepatan minimal $c^{*}=\sqrt{4 D_{1} \theta}, \varepsilon_{1}-b_{2}+d_{2}+\frac{\sigma \beta\left(1+\varepsilon_{2}\right)}{\vartheta_{2}}-\varepsilon_{2}=\theta$ dengan persistensi strongly uniformly persistence

\section{Lokasi 2}

Virus H1N1-p dengan kecepatan minimal $c^{*}=\sqrt{2 D_{1} \xi}, b_{1}+d_{1}-\varepsilon_{2}+\varepsilon_{1}+\delta=$ $\xi$ dengan persistensi weakly uniformly persistence.

Virus H5N1 dengan kecepatan minimal $c^{*}=\sqrt{4 D_{1} \theta}, \varepsilon_{1}-b_{2}+d_{2}+$ $\frac{\sigma \beta\left(1+\varepsilon_{2}\right)}{\vartheta_{2}}-\varepsilon_{2}=\theta$ dengan persistensi strongly uniformly persistence

\section{Global}

Virus H5N1 dengan kecepatan minimal $c^{*}=\sqrt{8 D v}, v=b_{2}-d_{2}+\frac{\beta \sigma \varepsilon_{2}}{\vartheta_{1}}+\frac{\beta \sigma}{\vartheta_{1}}-\varepsilon_{1}+\varepsilon_{2}$, dengan persistensi weakly uniformly persistence.

\section{Kesimpulan dan Saran}

Kesimpulan yang dapat dilakukan dari penelitian ini adalah

1. Belum nampak adanya reassortment diantara virus influensa H5N1 dan $\mathrm{H} 1 \mathrm{~N} 1$ walaupun pada transmisi virus $\mathrm{H} 5 \mathrm{~N} 1$ dikonstruksi terjadi antara manusia ke manusia.

2. Asumsi terhadap penyebaran virus inluensa H5N1 adalah pandemik, hal tersebut mendelaki kebenaran terbukti bahwa kecepatan minimal bergantung pada rate transmisi dari virus $\mathrm{H} 5 \mathrm{~N} 1$ pada unggas.

3. Batasan terhadap gerakan individual pada lokasinya maupun bergerak pada lokasi lain sangat mempengarui proses terjadinya reassortment.

Saran yang diberikan dalam rangka untuk pengembangan penelitian ini adalah :

1. Perlu dikembangkan fungsi densitas Kernel lain yang lebih tepat sesuai dengan phenomena obyek.

2. Sebagai bentuk pengembangan dapat pula dilakukan untuk multilokasi multi strain sehingga potensi penyebaran virus yang lebih luas dapat diamati

\section{Daftar Pustaka}

[1] J. Arino, J. R. Davis, D. Hartley, R. Jordan, J. M. Miller and V.D. Drissche, "A multi-species epidemic model with spatial dynamic", Mathematical Medicine and Biology.22 (2005), p. 129-142.

[2] S.AI and W. Huang, "Traveling Wave for a Reaction-Diffusion system in population Dynamic and Epidemiology", Proccedings of the Royal Soceity of Edinburgh 135A (2005), p.663-675.

[3] K.B. Blyuss, "On a model of spatial spread of epidemics with long distance travel", Physics Letters A 345 (2005), p. 129-136.

[4] H. W. Hectcote H W, "The mathematics of Infectious Diseases", SIAM 42 (2000), p.599-653. 
[5] M. Hyman, T. La Force, "Modelling The spread of Influenza Among Cities", in Computational and Applied Mathematics Program, (Center for Nonlinear Studies, Los Alamos National Laboratory), Los Alamos Report 2004, p. 215-240.

[6] W. Joseph, H. So, W. Jianhong and X. Zou, "A. reaction-diffusion model for a single species with age structure: Traveling wave fronts on unbounded domains", Proc. R. Soc. Lond. A 457 (2001), p. 1-13.

[7] C. Lie, M. Hatta, C. A. Nidom, Y. Muramoto, S. Watanabe, G. Neumann, "Reassortment between avian H5N1 and human H3N2 influenza virues creates hybrid virues with substantial virulence", PNAS (2009), p. 1-6.

[8] J. Li and X. Zou," Modelling Spatial Spread of Infectious Diseases with a fixed latent period in a spatially continous domain", Buletin of Mathematical Biology (2009), p.1-36.

[9] M. Lewis, J. Renclawowicz, P.V.D. Driessche, 2006, "Traveling Waveand Spread Rate for a West Nile Virus Model", Buletin of Mathematical Biology 68 (2006), p.3-23.

[10] C. A. Nidom, "Berperang Melawan Flu Burung", Kompas.Com (2012).

[11] S. Ruan, "Spatial Temporal Dynamics in nonlocal Epidemiogical Models", Miami University Press (2006).

[12] Riviera J, Y. Li, "Eksistence of Traveling Wave Solution for A Nonlocal Reaction-Diffusion Model of Influenza a Drift", Discrete and Continue Dynamical System Series B 13(1) (2010), p.157-174.

[13] Widodo. B, Sing M, "Numerical Solution of Flood Routing Model Using Finite Volume Methods", Studies in Nonlinear Sciences 2(1):40-45,2011

[14] Zhang FF, G. Huo, Q-X. Liu, G-Q Sun and Z. Jin," Existence of Traveling wave in nonlinear Si Epidemic Models", Journal of Biological System 17(4) (2009), p.1-15. 